\title{
FEATURES OF PUBLIC ADMINISTRATION IN SHAPING STRATEGY OF VENTURE INVESTMENT OF BUSINESS ENTERPRISES
}

\author{
Ivan Parubchak', Halyna Hrynyshyn²
}

\begin{abstract}
The purpose of this study is to define the content of the category "venture investment", and to establish the relationship between the concepts of "venture investment" and "venture capital", to analyze the state of venture investment in Ukraine and determine its role in innovative development of the economy, to systematize international experience consider the possibility of its adaptation in Ukraine. Object of research: venture capital in the system of financing innovation processes in the modern economy. The methodological basis of the study is a set of general scientific and special methods of cognition. Methods of analysis and synthesis, generalization and scientific abstraction were used in the formation of the conceptual and categorical apparatus. The analysis of approaches to understanding the essence of venture investment, its components was carried out using dialectical and systemic-structural methods. The application of the historical and logical method, induction and deduction made it possible to study the genesis of the theory of economics and enterprise management, the factors of the strategy of development of venture investment of business entities. Within the framework of the study of the current state of venture investment, calculation and analytical methods of observation, measurement, analysis and comparison are used. Conclusions. Based on the above study, we can assume that venture capital is a combination of financial, human and intellectual resources, which with a high level of risk is invested in the development and implementation of high-tech products of companies that are in their infancy and initial development and are not listed on the stock market and in case of success brings its owner a profit that is much higher than the industry average. Despite the riskiness of investments, venture investments have a number of attractive prospects and advantages. As world experience shows, venture-backed companies are better prepared to innovate, grow faster and create more jobs in the future.
\end{abstract}

Key words: venture investment, venture capital, innovations, investment fund, investments, association, financial institutions, company, startups.

JEL Classification: E22, G24, H83

\section{Introduction}

A characteristic feature of the modern economic space of Ukraine is the formation of a multi-stage model of innovation. Its structuring and institutionalization with the separation of functions, tasks between different business entities allows to reflect the attitude of different types of people to the risk and activities associated with it. The construction of this model and its application in the system of public administration is an urgent and important task today.

It is quite difficult for an innovative business entity to function and develop in conditions of turbulence (uncertainty), much more difficult than in a developed market economy. Increasingly, the use of modern innovation management brings a huge economic effect to the business entity at relatively minimal cost. But the potential of science and the possibility of its practical implementation are completely different things. Economic conditions in Ukraine today differ from those of developed economies, so the use of the potential of innovation management should take into account the characteristics, traditions and specifics of the country as a whole, each region or individual entity.

In the conditions of unstable macroeconomic and political situation, and as a result, strengthening of deficit of investment resources, which would allow

\footnotetext{
Corresponding author:

${ }^{1}$ Stepan Gzhytskyi National University of Veterinary Medicine and Biotechnologies Lviv, Ukraine.

E-mail: parubchak io@ukr.net

ORCID: https://orcid.org/0000-0002-7664-5062

${ }^{2}$ Stepan Gzhytskyi National University of Veterinary Medicine and Biotechnologies Lviv, Ukraine.

E-mail: halynahrynyshyn0802@gmail.com

ORCID: https://orcid.org/0000-0001-5224-9631
} 
to increase indicators of efficiency of activity of the enterprises of Ukraine, one of long-term tools of realization of financial mechanisms could become venture investment providing financing of new, risky projects or unprofitable companies in order to increase their capitalization.

A significant contribution to the development of theoretical and practical principles of venture capital, the functioning of venture capital and its forms, corporate finance was made by foreign scientists: O. Ardishvili, D. Arom, V. Benevolensky, O. Dagaev, P. Drucker, R. Clark, A. Karzhauv, E. Lebedeva, J. Rivkina, O. Rogova, I. Rudakova, E. Ruzavina, O. Tkachenko, E. Fiaxel, D. Frear, R. Hofat, N. Shekhovtsova and others.

World economic studies the problems of venture capital in a developed market economy, particularly, the knowledge economy. In Ukraine, the conditions for the development of venture capital are just being formed. Theoretical and methodological problems of its formation are reflected in the works of famous domestic economists, among which there are the works of V. Andriychuk, O. Amosov, V. Bondarenko, O. Borodina, O. Bugrov, M. Butko, V. Varena, I. Goncharenko, I. Grishova, A. Guley, A. Dagaeva, M. Demyanenko, I. Dvorak, O. Zalotov, V. Onegina, I. Dakhno, O. Ivanytska, O. Krasnorutsky, M. Klapkiv, Y. Lupenko, O. Mityai, V. Martynenko, V. Margasova, L. Naumova, A. Peresada, P. Sabluk, O. Ulyanchenko, O. Chechelyuk, L. Chernyuk, S. Shkarlet and others. However, the problems of formation and use of venture investment in the process of transition of processing enterprises to investment and innovation model of development require further research and finding ways to solve them.

\section{Research of the content of the category "venture investment", by establishing the interdependencies between the concepts of "venture investment", "venture capital"}

The term "venture" means "risk", "risky business", "dare", in general, all its definitions are somehow related to courage and adventure. The concept of venture capital can be interpreted in different ways. Some understand it as only a high-risk investment aimed at financing risky innovative high-yield projects in promising industries for an average of 3 to 5 years or even business ideas. Others prefer a broader interpretation, which includes any financing for the company's rapid growth. Thus, in this case, venture capital finances not only the formation of start-up capital, but also the next stages of formation of an innovative enterprise. Venture capital is a link between investment and innovation as components of economic growth, a source of capital for companies whose rapid growth and development constantly requires additional foreign investment (usually small and medium-sized enterprises). The main difference from traditional investing is that financial assets are provided to the company without any guarantee of provision of movable or immovable property or savings. The only guarantee is the relevant part of the shares, less than the controlling stake of the existing or just created company, scilicet venture capital is provided to the company for a promising idea.

Internal venture refers to specialized units created by large corporations, whose function is to select and implement risky ideas and projects. The purpose of an internal venture is to find new ideas, technologies, objects and inventions. The corporation, as a rule, gives internal ventures legal and budgetary independence, the right to form staff (Vashchenko, Kuzmich, Syzov, 2010).

An external venture is considered to be small independent science-intensive firms founded by the authors of the idea - scientists, engineers, inventors and a venture entrepreneur who try to implement new advances in science and technology with the expectation of material gain (Velyka, 2012).

The peculiarity of venture investing, which distinguishes it from other strategic investors, is also that the venture capitalist does not seek to acquire a controlling stake in the company, and therefore does not seek to control the company that falls within his or her interests. The venture investor hopes that the company will use his or her money as a financial instrument to ensure the rapid growth and development of the business, realizing that the implementation of science-intensive projects for various reasons does not always end with the expected end results. Wellknown venture capitalist Tim Draper noted: "Venture business is when 10 companies invest, half of them go bankrupt, three return, one gives a 10 -fold increase, and another profit is 100 times higher than the investment" (Zinchenko, Ilchuk, et al., 2004). The expectation of making very high profits also forces the venture capitalist to take exorbitant economic risks.

By studying the economic literature, one can obtain numerical definitions of venture capital. Each author gives his or her own interpretation of this concept, the term "venture capital" in each country has its own characteristics, associated primarily with the lack of strict state regulation of venture capital.

Venture capital, as defined by the European Private Equity and Venture Capital Association (EVCA), is equity capital provided by professional financial companies that is invested in start-up innovative enterprises that develop and demonstrate the potential for significant growth (The BVCA Private equity and Venture Capital Report on Investment Activity, 2012).

The Canadian Venture Capital and Private Equity Association (CVCA) proposes the following definition: "private equity" is a general term that reflects the totality of all forms of equity and quasi-equity investments in the market. In a mature (developed) equity market, 
there are usually three main segments: buyout capital, mezzanine capital and venture capital. In turn, venture capital is defined as a specialized form of private equity, which is characterized mainly by high-risk investments in new or young companies seeking to grow in technology and other industries that create high added value (Weiss, 2000).

The Australian Private Equity and Venture Capital Association Limited (AVCAL) interprets the concept of venture capital as capital that has independent management and is invested in private companies with high growth rates.

Experts of the British Private Equity and Venture Capital Association justify the essence of venture capital as an investment in the share capital of unregistered companies, which are in both initial and later stages of development, when the acquisition of the company requires significant financial resources.

The Russian Federal Agency for Science and Innovation believes that venture capital is a long-term investment, which is realized during the sale of its share in the company through an IPO (initial public offering of shares on the stock market), scilicet the main thing to increase the price of the newly created company and sell it profitably in 3-5 years (All about marketing, 2000).

I. Dvorak, J. Kochyshova and P. Prokhazka emphasize the orientation of venture capital to high risk and the implementation of scientific and technological innovations, based on empirical analysis of venture capital in the Anglo-Saxon model countries (the USA, Canada, the UK) and innovation-oriented capital in Western Europe (Krasovskaya, 2013).

A. Lapko reviewed the role and functions of venture capital in solving problems of formation of infrastructure of innovative economy and the acceleration of structural changes in favor of high-tech industries, paying special attention to the peculiarities of the establishment and functioning of venture companies in Ukraine and factors that hinder its development, justified ways to speed up the formation of venture capital (Lapko, 1999).

Based on the above study, we can assume that venture capital is a combination of financial, human and intellectual resources, which with a high level of risk is invested in the development and implementation of high-tech products of companies that are in their infancy and initial development and are not listed on the stock market and in case of success brings its owner a profit that is much higher than the industry average.

Like any activity related to stocks, venture capital investments carry a certain risk, which is manifested, first of all, in the following:

1. This type of investment is directed to enterprises whose shares are not listed on the stock exchange. That is, investments are not directed to those companies that are already profitable in the market, having a certain customer base, and young but promising companies that are potentially able to increase the money invested in them.

2. Venture capital investments are invested for a long time, and the investor has no opportunity to return their money before its completion.

3. Typically, such investments are directed to companies that have some "highlight", an innovation that will either bring a profit, or fail miserably.

Despite the riskiness of investments, venture investments have a number of attractive prospects and advantages. According to world experience, venturebacked companies are better prepared to innovate, grow faster and create more jobs in the future.

\section{Trends in venture business development in Ukraine, its dynamic characteristics}

In order to establish an innovative model of economic development and ensure the expanded reproduction of innovation processes, systemic problems must be solved, including those related to the financial support of innovation processes, a key place among which should be occupied by venture investments and venture capital market development.

According to the Decree of the President of Ukraine "On Investment Funds and Investment Companies" dated February 19, 1994, the first domestic venture fund was the Ukraine Fund, managed by Claflin Capital Management (Boston, USA). A large share of investment in this fund was made by the European Bank for Reconstruction and Development.

Since the beginning of its activity in Ukraine, the bank has invested more than 22.5 million USD in 31 Ukrainian enterprises. It was formed for 10 years in the amount of 40 million USD especially for investments in Ukraine. Among the largest investors of the fund there have been EBRD, IFS, BankBoston, Commercial Capital-Athens, Creditanstalt-Vienna. The fund invests in private enterprises operating in the field of production of consumer goods and services in the domestic market. The investment strategy provides an initial contribution of 250-400 thousand dollars with an increase in investment, if successful, to 1 million USD. The return on investment in the fund is about $40 \%$ per annum (Public administration, 2002).

The beginning of international venture investment in Ukraine is considered to be 1993, when the Tokyo Summit between the governments of the G7 and the European Union adopted an Agreement to support newly privatized enterprises under the State Program of Mass Privatization, under which about 15,000 small and medium enterprises worked.

The creation of venture funds in Ukraine can be divided into several stages. The first period is considered to be 1992-2001, which is characterized by the creation and operation of 7 venture funds in Ukraine through foreign investment. For the period up to 2004, the total 
investments of these funds amounted to more than 127.5 million USD in more than 106 companies.

In 1994, mass privatization began in Ukraine. To service this process, investment companies and funds were actively created, which, according to the Decree of the President of Ukraine "On Investment Funds and Investment Companies", could attract only privatization property certificates, which were later invested in auctions of the State Property Fund of Ukraine. 1994 is considered the beginning of the development of mutual investment institutions.

Since 1994, another venture fund "Western Nis Enterprise Fund" with a capital of 150 million USD has been operating in Ukraine, and in 1998, it began to operate on the Black Sea Fund. These two funds are still operating successfully. A large share of funding from these funds is provided by the European Bank for Reconstruction and Development. In the same year, Evroventures Ukraine (capitalization 30 million USD) was established and began operations in 1999.

Between 1994 and 1996, 11 regional venture funds were gradually established in partnership with the European Bank for Reconstruction and Development (EBRD), which provided 310 million USD. US equity financing in Kyiv, and donor countries (France, Germany, Italy, Japan, USA, Finland, Norway and Sweden), which provided 207 million USD in unpaid loans.

Thus, in Ukraine until 2005, only three financial institutions (Western NIS Enterprise Fund, EuroVentures, and Ukraine Fund) operated on a permanent basis in the field of venture financing, which almost completely ruled out the possibility of competition between them.

Venture funds in Ukraine became more active after the adoption of the Law of Ukraine "On Joint Investment Institutions" by the Verkhovna Rada in 2001.

The second stage of development of venture funds is considered to be 2001 .

According to the Ukrainian Investment Business Association, in 2004-2010, the number of venture funds increased 13.9 times and the value of net assets increased 63.1 times, the growth rate of these indicators slowed more than 2 times during this period, the largest slowdown was observed after the global financial crisis in 2008.

The concept of "venture business" is included in the Laws and acts of Ukraine, namely - in the Decisions of the State Commission on Securities and Stock Market No. 8 and 9 dated January 8, 2002, in the resolution of the Verkhovna Rada "On compliance with legislation on scientific and technical development potential and innovation activity in Ukraine" dated June 16, 2006, however, the essence, functions, principles of activity of venture funds and venture firms have not been defined yet. Relations in this area are also partially regulated by the Laws of Ukraine "On Investment Activity",
"On Innovation Activity", "On Scientific and Scientific Technical Activity", "On Scientific and Scientific Technical Expertise”.

In December 2005, Draper Fisher Jurvetson (DFJ), which includes 20 funds with a total investment capital of more than 3 billion USD, opened the DFJ Nexus technology venture fund in Ukraine. Over the next 10 years, the fund plans to raise from 50 to 100 million USD for the development of high-tech companies in the countries of the former USSR.

We consider the period up to 2008 to be the third stage of venture business development in Ukraine.

In 2008, the State Agency for Investment developed a draft Law of Ukraine "On Venture Funds for Innovative Development". For the first time in Ukraine, the bill attempts to define the legal basis for the creation of a new financial instrument that would ensure the direction of investment flows into innovative sectors of the economy.

This document states the following: the founders and participants (shareholders) of the venture fund of innovative development may be individuals and legal entities, residents and non-residents, as well as the state and local communities; venture capital funds can invest in corporate rights and debt obligations of innovative enterprises; joint ventures established to implement technology parks and science parks; Venture capital assets of innovative development may consist of corporate rights, debt obligations, real estate and intellectual property rights; venture funds of innovative development invest in innovative programs and projects, new knowledge and intellectual products, production equipment and processes, infrastructure of production and entrepreneurship, etc.

The fourth stage is the post-crisis year of 2009, which is characterized by a slowdown in the growth rate of Join Investment Institution assets.

The next period of venture investment development from 2010 to 2013 was unfavorable for the Ukrainian stock market and asset management activities. The realities were the general deterioration of the investment climate in the country, the lack of clear and stable rules of the game, the shortage of reliable financial instruments, unequal conditions for taxation of investment funds and bank deposits, tighter regulations and increased fiscal pressure.

2014 was one of the most difficult years for the Ukrainian sector of asset management of institutional investors, as well as for the whole country, in the previous history, political instability, annexation of Crimea, military actions in the east, devaluation of assets, numerous attempts to fill the budget and change mechanisms for taxing the activities of collective investment institutions, the outflow of investors, but even such negative factors were not as destructive as might be expected. At the end of 2014, the assets of venture companies amounted to 202.85 billion UAH. 
Since 2014, the Ukrainian Venture and Private Capital Association (UVCA) has been creating a positive image of Ukraine in the world and promoting Ukrainian startups, uniting about 50 venture funds, direct investment funds, accelerators, incubators and non-profit institutions.

The next stage of venture business development is 2017, which became a record in the history of Ukrainian venture business - startups raised 258.6 million USD, which is three times more than in 2016. This confirms the fact that Ukrainian startups create highly competitive products that can meet the needs of consumers around the world. A striking example is the Grammarly application, an online grammar checker service that raised 110 million USD. It should be noted that in 2017, the venture market had 16 sales, while in 2016 there were only 6 . This is a positive sign for investors.

In recent years, we have seen a steady growth of the Ukrainian investment market. Although the COVID-19 outbreak has made some adjustments to investor plans and startup development, understanding the trends of 2019 will be useful for investment market players to manage expectations, support and grow their business in the new reality.

For the first time, the volume of investments in Ukrainian startups and IT companies reached half a billion a year. The total amount of venture investments in Ukrainian IT companies reached 510 million USD, which is one and a half times higher than the maximum in 2018. The number of transactions in 2019 was almost the same as in 2018: 111 transactions compared to 115 in 2018. In 2019, the volume of M\&A operations (mergers and acquisitions) increased 18 times. 15 M\&A deals amounted to 460 million USD, while in 2018 there were 7 deals worth 25.2 million USD. Despite the fact that in 2019 the country went through elections, investment in a number of industries continued to grow. In particular, in areas related to software development, hardware products and online services. And although 2020 makes its adjustments, the report shows that Ukraine really has significant potential for investment. As soon as the economic situation in the world stabilizes, Ukraine will be able to boast of new investment growth.

The analysis of venture activity of the abovementioned foreign companies in Ukraine showed that, firstly, they do not adhere to the main goal of venture business - investing in the search and implementation of "new, innovative idea", but reduce their activities to investing in profitable and almost risk-free economy. Secondly, all possible surplus profits created in Ukraine are outside it, because there is not even a share of Ukrainian money in these funds (Deineko, Tsymbalyuk, Romanchyk, 2000).

In Ukraine, there are a number of factors that can contribute to the development of venture capital, namely - the availability of cheap highly qualified and creative staff; convenient geographical location; large reserves of raw materials; powerful assets abroad owned by residents of Ukraine, etc. Even the best of the investment projects offered in Ukraine today are not ready for venture investment. Attracting funds from Ukrainian sources is extremely difficult. Looking at traditional sources, we can note either a very weak development of this sector of the economy, or unfavorable legislation and lack of commercial interest due to high risk.

\section{Evaluation of international experience in developing, supporting and stimulating venture investment and the possibility of its adaptation to the conditions of the Ukrainian economy}

Venture capital is one of the oldest types of capital. It comes from the moment when a person who came up with an innovative business idea asked his or her relatives or friends to invest a certain amount of money in his or her business, offering part of the profits in the future. Americans jokingly say that "sources of investment in a new business can be three " $\mathrm{f}$ ": family, friends, fools (Oliver, 1996).

Significant venture capital has been used to finance high-risk projects since the Middle Ages. During the Great Geographical Discoveries, the owners of large capitals provided money to travelers and resourceful entrepreneurs.

Today there are 2 markets for venture capital: the first - the US and Canadian markets, the second Europe. Of course, the European market is understood as the market of Western Europe. The markets of Southeast Asia, Israel, Brazil, India and Australia are also considered promising. Experts differ on China's potential, but we believe it is promising and needs more in-depth analysis and research. Their differences can be traced in the following areas: first of all, in the role of the state in innovation processes; by sectors of the economy in which venture funds invest; by venture capital objects.

In Europe, venture entrepreneurship began to develop actively in the early 80 s of the twentieth century, although, of course, the practice of risky investing in European countries existed before. The dynamic development of this industry is largely due to the presence of more than twenty years of experience in American venture business. In particular, the main stages of infrastructural development of the European venture business largely repeat the American experience.

In Europe, the state takes an active position in the venture business, it is expressed in the following: the state acts as a direct investor in small venture companies; with the help of tax policy instruments a favorable climate is created for the operation of venture firms. Thus, in the UK for venture firms reduce income tax $(25 \%)$, there is a system of insurance, written off the 
cost of research and development work on the cost of production (in any amount).

In Germany, there is a tax rebate on private investment in research and development (up to $7.5 \%$ ). In France, funds invested in risky projects are not taxed. Financing of scientific and technical works was carried out at the expense of the state budget at the level of $0.74 \%$ of the gross domestic product in 2010.

For comparison, in Ukraine the funding of scientific and scientific-technical works is about twice less, which is only $0.34 \%$ of gross domestic product (European Venture Capital Assosiation). In Europe, venture financing emerged in the 1970s and 1980s and, with rare exceptions, is a purely national phenomenon. Only British venture capital funds have branch networks across Europe. Other European venture capital funds that have opened offices outside their home country consider it appropriate to work with either the United States or Asia.

The European Venture Capital Association (EAOC), established in 1983, publishes annual reports describing the activities of national venture capital in different countries. Venture capital in Europe, based on EWC data, is most developed in the United Kingdom, Germany and France. Quantitative data on a slight decrease in venture capital due to the saturation of the Internet market.

In the UK, several regimes of tax benefits have been developed (NVCA Yearbook, 2016):

- The Enterprise Investment Scheme provides for a reduction in the investor's income tax by an amount equivalent to $20.0 \%$ of the investment. The company must be paid at least 500.0 GBP, and the maximum amount of investment, for which a tax benefit is possible, which is 500.0 thousand GBP. Income from the sale of shares or stakes in the company is also not subject to capital gains tax. There is a tax mechanism to compensate for investor losses. Income from the sale of shares after the expiration of five years is also not taxable;

- Reinvestment Relief (reinvestment tax benefits) - deferrals of tax payments are provided subject to reinvestment of income received by the investor within three years from the date of investing in shares of companies not listed on stock exchanges;

- Regional Venture Capital Funds (RVCF) - providing small and medium enterprises with venture financing in the amount of up to 500.0 thousand GBP on a commercial basis. Each such fund is managed by a management company that has experience in the private sector and has been rigorously selected. The volume of funds averages 30.0 million GBP. About $50.0 \%$ of the funds of each regional fund belong to the state or the European Investment Fund (a division of the European Investment Bank). Regarding payments, the "first victim" rule applies in favor of the fund's private investor.
In Finland, the catalyst for the development of venture capital was the state seed investment fund SITRA. The average annual investment is 30.0 million EUR. There is also a "fund of funds" Finnish Industry Investment in Finland. The catalyst for the development of venture capital in Israel was the state fund Yozma, which co-invested in privatestate venture funds under the management of private management companies (usually foreign). Yozma's share in the fund reaches $40.0 \%$.

In 1995, Germany developed a scheme called Beteiligungskapital fur Kleine Technologieunternehmen, which financed small firms producing innovative products or services together with private sector companies. Austria is also setting up an "Investment Innovation Fund" to increase funding for start-ups by providing funds to private funds. The European Investment Fund, established in 1994 with the financial support of the European Commission, invests in stocks of small and medium-sized enterprises with high growth potential. Loans offered by governments, often unavailable from other sources, are often provided on more attractive terms than private loans. They may have lower interest rates or longer payback periods. They can even be irreversible. The governmentfunded Vaekstfonden (Business Development Credit Financing Program) in Denmark, for example, provides loans to small firms to develop technology-oriented projects. In this case, in case of failure, the cancellation of debts is provided. In the Netherlands, the technical development credit scheme provides for the issuance of ten-year loans to small companies, which may not be repaid in the event of technical or commercial failure. In Sweden, the government is the largest shareholder in AlmiForetagspartner $\mathrm{AB}$, which provides 6-10-year interest-free loans to start-ups for the first two years.

In the European countries, the state is the driving force of venture business and a stimulus, in contrast to private capital, which dominates in North America. Currently, the venture financing mechanism is the most developed in the United States, due to the large number of small high-tech firms in this country and the development of the stock market. An important feature of venture investment in the United States is that significant amounts of money are invested in the development of high-tech companies in the early stages of development (up to 30\%), while in Europe this figure is twice lower. It is worth noting that a characteristic feature of business in the United States is its focus on innovative enterprises in the field of high technology. Statistics show that suppliers of more than $60 \%$ of major innovations of the 20 th century are venture firms. This is how the personal laptop, color photo paper, electrography, vacuum lamps, microprocessor, etc. appeared. The world leaders in the computer industry - Microsoft, Intel, Apple Computers, Compaq - gained their current position largely due to venture capital in the early stages of its development. 
In the United States, at the initial stage of development of the national venture system, specialized small business investment companies (SBIC) were established. SBIC's private investors have been given significant tax breaks, as well as certain government guarantees and relatively cheap loans. Several billion dollars are received annually in "sowing" projects under the state support programs SBIR and STTR.

In the American model of venture financing, the main purpose of the state is to integrate and promote the interaction of industrial and scientific sectors. The state is assigned the role of a "night watchman", which does not significantly interfere in the promotion of the venture project and performs legislative regulation of venture processes, as well as stimulates the development of the venture industry.

Consider the main means of stimulating the development of venture business in the United States: 1) preferential taxation of venture firms; 2) no rental tax; 3) guaranteed return of private capital invested in venture business by the Small Business Administration; 4) mandatory involvement of venture firms in the implementation of major innovation projects in accordance with US law.

Obviously, the venture capital industry in Europe differs from its American counterpart in two main respects. Firstly, unlike the United States, which invests in venture capital in new technologies, in Europe, venture capital is invested mainly in developed industries, transport and communications. Secondly, the main institutional investors in the European venture capital (excluding the United Kingdom and Poland) are banks. And in the United States - it is the pension funds, insurance companies, sponsors and individuals. In the regional aspect, the ratio of venture capital in the US and Western Europe is about the same. However, Western Europe is represented by 17 countries with a population one and a half times the population of the United States, and if we compare the two regions in terms of venture capital per capita, the leadership of the United States is unconditional.

There is an urgent need for Ukraine to develop a competent state policy to stimulate venture business, taking into account the leading foreign experience. The state should share the risks of innovation with business and improve legislation to stimulate innovation, modes of operation of technology parks, the autonomy of the Ukrainian universities. Today, the development of the venture industry in Ukraine is constrained by a weak legal framework, underdeveloped stock market, nontransparency of financial activities of companies, lack of guarantees for investors. While the decisive role in the development of the venture industry in the United States and Europe was played by public policy measures to create favorable conditions for the development of venture funds.

It makes sense for the state to actively promote the development of venture business, because the benefits that society receives from venture capital support programs are not limited to the profits of venture investors. Venture investments: 1) contribute to the development of new leading scientific and technical developments to create competitive high-tech products and technologies; 2) create new jobs, helping to reduce unemployment and increase welfare in society, which is of strategic importance for long-term growth of the national economy.

\section{Conclusions}

Analysis of the main trends of venture investment, as well as the study of the current state of venture processes in Ukraine and in the world provides an opportunity to draw meaningful conclusions. Venture capital investment plays a special role in ensuring the attraction of long-term, high-risk capital, which has a predominant focus on the intensification of scientific, technical and innovative activities, which is the key to economic development of the country.

For Ukraine, the development of venture investment is an opportunity not only to stabilize the economy, but also to provide it with significant growth rates. Ukraine has rather low volumes of investment, which is caused by the lack of trust in investment funds in the population, the instability of the economic situation, in which it is very difficult to predict the future outcome of investment. Systematization of venture capital functions allowed to highlight the following features of its formation in Ukraine: 1) the need to accumulate financial resources, which allows to attract sufficient investment in knowledgeintensive innovative entrepreneurs and promising innovative projects that, according to the venture investor, will pay for itself investment; 2) increasing the rate of return in the venture business compared to the average in the economy allows to attract foreign venture capital in this area, which acts more prudently and aggressively, helping selected innovative enterprises to increase capitalization and create a positive image in the market; 3 ) the formation of a more progressive production structure by increasing the share of enterprises with a high level of value added, and, accordingly, additional revenues to the budget; 4) providing financial resources to small and medium-sized innovative enterprises, which in the current geopolitical situation is necessary and vital, because, given the severe budget deficit and lack of own funds to develop and implement their results, access to other sources of financial resources for them almost impossible.

Prominent examples for the country are the United States and Europe, where this type of financing for enterprise development is very common. The United States is characterized by a growing trend of venture capital investment in the economy, and in this sector there are many types of investors and investment objects. 


\section{References:}

Vashchenko, I. V., Kuzmich, O. I., \& Syzov, A. I. (2010). The current state of the organization of wages of workers in the Armed Forces of Ukraine. Bulletin of Kyiv National University. Taras Shevchenko. Military special sciences, vol. 25, pp. 84-87.

Velyka, K. V. (2012). Organizational forms of venture business: features and advantages. Bulletin of socio-economic research, vol. 2(45), p. 157-162.

Zyanko, V. V., \& Epifanova, I. Yu. (2015). Innovative activity of enterprises and its financial support in the conditions of transformational changes of economy of Ukraine. Monograph. Vinnytsia: VNTU, $172 \mathrm{p}$.

Zinchenko, O. P., Ilchuk, V. P., et al. (2004). The state of development of organizational forms of venture entrepreneurship and its infrastructure in the countries of the world and in Ukraine. Kyiv: NDESEP, 80 p.

The BVCA Private equity and Venture Capital Report on Investment Activity (2012). Available at: http://www.bvca.com.uk/

Weiss, K. G. (2000). Evaluation: methods of research programs and policies. Kyiv: Foundations, 671 p.

All about marketing: collection of materials for managers of enterprises, economic and commercial services (2000). Moscow.

Krasovskaya, O. V. (2013). Venture financing: global trends and the situation in Ukraine. Kyiv: Cone-Yu, 108 p.

Lapko, O. O. (1999). Innovative activity in the system of state regulation. Kyiv: IEP NASU, 254 p.

Public administration: dictionary-directory (2002). Kyiv: Press ADU, 228 p.

Deineko, L. V., Tsymbalyuk, A. V., \& Romanchyk, I. M. (2000). Development of food industry in the context of food security. Ekonomika promyslovosti Ukrainy. Kyiv: RVPS of Ukraine, National Academy of Sciences of Ukraine, pp. 123-130.

Oliver, N. (1996). Benchmarking Product Development. Working Paper, Judge Institute of Management Studies, University of Cambridge.

European Venture Capital Assosiation. Available at: http://www.evca.org

NVCA Yearbook (2016). National Venture Capital Association. Available at: http://nvca.org/research/statsstudies 